\title{
MODEL TEORITIK REGULASI DIRI, MOTIVASI BERPRESTASI, HARGA DIRI DENGAN KEMATANGAN KARIR MAHASISWA BIMBINGAN DAN KONSELING ISLAM IAIN TULUNGAGUNG
}

\author{
Muhammad Sholihuddin Zuhdi \\ IAIN Tulungagung \\ Email: zuhdi.bk@gmail.com
}

\begin{abstract}
ABSTRAK
Penelitian ini bertujuan untuk menguji menguji model teoritik kematangan karir dan pengaruh harga diri, regulasi diri, dan motivasi berprestasi terhadap kematangan karir mahasiswa bimbingan dan konseling islami. Metode yang digunakan dalam penelitian ini adalah Causal Relationship Study dan analisis data adalah uji statistik yakni struktural equation modelling (SEM). Hasil uji hipotesis melalui analisis SEM diperoleh kesimpulan bahwa model teoritik kematangan karir mahasiswa bimbingan dan konseling islam telah terbukti layak $(G F I=0.924$ dengan kriteria $>0.900)$ dan memperoleh dukungan data empiris $\left(x^{2}=149.799, p=0.398\right.$ dengan kriteria $\left.>0.05\right)$, serta harga diri mempengaruhi motivasi berprestasi, regulasi diri mempengaruhi motivasi berprestasi, harga diri mempengaruhi kematangan karir, regulasi diri mempengaruhi kematangan karir, dan motivasi berprestasi mempengaruhi kematangan karir.
\end{abstract}

Kata Kunci: Regulasi Diri, Motivasi Berprestasi, Harga Diri, Kematangan Karir, Mahasiswa

\begin{abstract}
This study aims to discuss the theoretical model of career maturity and the effect of price, self-bonding, and achievement motivation on the career maturity of Islamic guidance and counseling students. The method used in this study is a Causal Relations Study and data analysis is a statistical test with structural modeling (SEM) equations. The results of hypothesis testing through SEM analysis concluded that the theoretical model of student career maturity in Islamic guidance and counseling has been proven feasible $(G F I=0.924$ with criteria $>0.900)$ and obtained empirical data support $(x 2=149.799, p=0.398$ with application> 0.05), and self-esteem affects achievement motivation, selfregulation affects achievement motivation, self-esteem affects career maturity, self-regulation affects career maturity, and achievement motivation influences career maturity.
\end{abstract}

Keywords: Self Regulation, Achievement Motivation, Self-Esteem, Career Maturity, Students 


\section{PENDAHULUAN}

Mahasiswa memiliki usia yang tidak lagi bermain dengan teman seusianya, namun mahasiswa juga harus memulai memikirkan kehidupanya di masa yang akan datang terutama dalam menyiapkan kemandirian ekonomi dan karir yang harus dipilih dan disiapkan. Individu yang dapat memutuskan dan menjalani karirnya dengan baik maka individu tersebut dapat dinggap telah menyelesaikan tugas perkembangan karirnya, hal tersebut sesuai dengan yang dinyatakan Patton W dkk (2001) bahwa Kematangan karir adalah keberhasilan individu menyelesaikan tugas perkembangan karir yang khas pada tahap perkembangan karir. Dalam kematangan karir banyak hal yang mempengaruhinya salah satunya adalah aspek psikologis seperti harga diri, regulasi diri dan motivasi berprestasi.

Regulasi diri yang diartikan dimana seseorang menghasilkan suatu proses pikiran, perasaan dan tindakan, merencanakan dan mengadaptasikannya secara terus-menerus untuk mencapai tujuan-tujuan personal (Zimmerman, 2000). Seseorang yang memiliki regulasi diri terlibat secara langsung dalam membuat sebuah tujuan, memantau dan mengevaluasi kemajuan serta menyesuaikan strategi untuk mencapai tujuan (Senko \& Harackiewicz, 2005). Selain itu Zimmerman dan Kitsantas (2005) menemukan bahwa pencapaian prestasi dalam berkari membutuhkan lebih dari sekedar bakat dan pelajaran yang berkualitas, tetapi juga keyakinan diri, ketekunan, dan kedisiplinan. Hal tersebut menunjukkan adanya dimensi self-regulatory dalam suatu kompetensi yang sering kali tersembunyi dan luput disadari berperan besar menjadi salah satu faktor penentu keberhasilan.

Selain regulasi diri, motivasi berprestasi juga sangat berpengaruh terhadap keberhasilan karir seseorang, Ardhana (1990) menjelaskan bahwa motivasi berprestasi merupakan suatu faktor penting untuk mencapai prestasi, baik dalam berprestasi akademik maupun dalam bidang pekerjaan lain, sedangkan Slavin (1994) mengungkapkan bahwa satu jenis motivasi paling penting dalam berkarir adalah motivasi berprestasi (achievement motivation). Menurut McClelland (1987) seseorang dianggap mempunyai motivasi untuk berprestasi jika dia mempunyai keinginan untuk melakukan suatu karya dan berprestasi lebih baik dari prestasi orang lain. Seseorang yang memiliki motivasi berprestasi tinggi akan 
selalu melakukan yang terbaik, memiliki kepercayaan terhadap kemampuan untuk bekerja mandiri dan bersikap optimis, memilki ketidakpuasan terhadap prestasi yang telah diperoleh serta mempunyai tanggung jawab yang besar atas perbuatan yang dilakukan sehingga seseorang mempunyai motivasi berprestasi yang tinggi.

Selain motivasi berprestasi, harga diri juga memiliki pengaruh penting dalam keberhasilan mahasiswa bimbingan dan konseling. Menurut Santrock (2003), harga diri merupakan dimensi evaluatif yang menyeluruh dari diri seseorang, harga diri juga sebagai penilaian dari diri seseorang secara menyeluruh sehingga ia memperoleh gambaran yang jelas tentang dirinya sendiri, dan kemudian membandingkannya dengan kriteria ideal yang dimilikinya. Harga diri atau self esteem menurut Coopersmith (1967) adalah penilaian diri yang dilakukan oleh individu dan biasanya berkaitan dengan dirinya sendiri, penilaian tersebut mencerminkan sikap penerimaan atau penolakan, serta seberapa jauh individu tersebut percaya bahwa dirinya mampu, penting, berguna, dan berharga.

Harga diri atau self esteem mempunyai hubungan erat dengan prestasi seseorang, seperti hasil penelitian Puspitasari (2007) yang menemukan bahwa harga diri memiliki hubungan erat dengan karir seseorang. Semakin rendah harga diri siswa, maka semakin sulit seseorang mencapai keberhasilan karirnya. Penelitian lain yang dilakukan oleh Baldwin dan Hoffman (2002) yang dilakukan terhadap harga diri remaja menunjukkan bahwa di masa remaja ini harga diri individu cenderung mengalami penurunan yang disertai dengan kemunduran substansial dalam motivasi mencapai puncak karir.

\section{METODE}

Penelitian ini menggunakan rancangan penelitian nonexperimetal research, di mana dalam penelitian ini tidak melakukan manipulasi atau perlakuan terhadap variabe-variabel yang diteliti, tetapi penelitian ini hanya melakukan pengukuran terhadap variabel secara netral (Gall dkk. 2003).

Pengukuran dalam penelitian ini menggunakan Causal Relationship Study seperti yang diungkapkan Gall dkk. (2003) yang berarti jika ditinjau dari sifat hubungan variabel, penelitian ini tidak hanya sekedar menjelaskan hubungan, tetapi menjelaskan tingkat pengaruh antar variabel. 


\section{POPULASI}

Penelitian ini dilakukan pada mahasiswa Bimbingan dan Konseling Islam IAIN Tulungagung. Responden dalam penelitian ini mahasiswa bimbingan dan konseling islam angkatan 2015 dan 2016.

\section{SAMPEL}

Santoso (2012) mengemukakan bahwa sampel penelitian dalam SEM bila perkiraan parameter menggunakan metode kemungkinan maksimum (Maksimum likelihood/ML), atau alternatif lain GLS dan ULS akan efektif jika menggunakan jumlah sampel antara 150 data sampai 400 data. Namun bukan berarti data di bawah 150 atau data di atas 400 tidak dapat diproses, hanya jika jumlah data sedikit misalkan di bawah 100 maka akan bisa sehingga tidak dapat menghasilkan kesimpulan tertentu, dan jika jumlah terlalu banyak maka misalkan 500 maka ouput akan menunjukan model yang tidak layak untuk menjelaskan fenomena tertentu. sampel yang mendekati ideal untuk analisis SEM yang direkomendasikan Ghozali (2008) antara 100 sampai 200 sampel, dalam peneitian ini menggunakan seluruh mahasiswa bimbingan dan konseling islam angkatan 2015 dan 2016.

\section{ANALISIS DATA}

Teknik analisis data yang digunakan untuk menguji hipotesis dalam penelitian ini ada dua yakni analisis korelasi parsial dan analisis SEM. Analisis SEM (Structural Equation Modelling) menurut Gall dkk. (2003) dapat digunakan untuk a) menguji suatu model teoritis yang telah disusun untuk memperoleh dukungan empiris b) menguji signifikansi hubungan kausal antar variabel.

Analisis SEM (structural equation modeling) dilakukan dengan bantuan program AMOS versi 20.0. Secara prosedural ada tujuh langkah dalam analisis SEM (Ferdinand, 2002), yaitu: 1) pengembangan model berbasis konsep dan teori, 2) pengembangan diagram alur (path diagram), 3) konversi diagram alur ke dalam model structural (persamaan statistik), 4) memilih matrik input dan estimasi model, 5) menilai masalah identifikasi, 6) evaluasi goodness of fit, 7) interpretasi dan modifikasi model. 
JUANG: Jurnal Wahana Konseling (Vol. 2, No. 1, Maret 2019)

\section{HASIL DAN PEMBAHASAN}

Penelitan ini memiliki dua pengujian hipotesis yaitu hipotesis mayor untuk menguji dukungan empiris dari seluruh model yang telah dibuat dan hipotesis minor untuk menguji hubungan kausal antar konstruk. Pengujian hipotesis mayor dan hipotesis minor tersebut dilakukan dengan menggunakan aplikasi AMOS versi 20.0 Hasil analisis uji hipotesis mayor dan hipotesis minor akan di uraikan sebagai berikut.

\section{HIPOTESIS MAYOR}

Hipotesis penelitian ini bertujuan untuk membuktikan bahwa model teoritis yang dikembangkan tidak berbeda dengan model empiris sehingga model yang telah dikembangkan benar-benar mendapat dukungan empiris. Model SEM dalam penelitian ini menggunakan program AMOS versi 20.0 akan menghasilkan kesuaian model (goodness of fit) akan disajikan pada Tabel 4.2, kemudian nilainilai tersebut dibandingkan dengan nilai kritis (cut-off value) dari masing-masing indeks. Sebuah model yang layak adalah model yang memiliki goodnes of fit yang lebih besar atau sama dengan nilai kritis, jika model belum layak maka analisis SEM dengan menggunakan program AMOS versi 20.0 dapat dilakukan modifikasi model atas dasar yang dimunculkan program AMOS versi 20.0.

Pada model awal diperoleh diperoleh informasi bahwa hasil uji kelayakan model memiliki 5 kriteria yang memenuhi syarat yaitu RMSEA sebesar 0.096 memiliki nilai marginal, GFI sebesar 0.870 memiliki nilai marginal, AGFI sebesar 0.832 memiliki nilai marginal, TLI sebesar 0.890 memiliki nilai marginal, dan CFI sebesar 0.906 memiliki nilai marginal.

Hair, dkk (2006) menyatakan bahwa diantara banyak kriteria untuk mengetahui Goodness of fit suatu model, tidak harus semua digunakan tetapi cukup 4 kriteria yang memenuhi syarat agar tidak terjadi redudancy. Walaupun sudah memenuhi syarat tetapi nilai chi square memiliki nilai 404.133 yang berarti tidak baik dan signifikasi 0.000 yang berarti tidak baik, model ini belum layak dan memerlukan modifikasi sesuai yang disarankan dalam dialog box modification indices yang menyarankan bahwa menambahkan jalur korelasi antara konstruk eksogen harga diri (HD) dan regulasi diri (RD). 
JUANG: Jurnal Wahana Konseling (Vol. 2, No. 1, Maret 2019)

Gambar model struktur awal

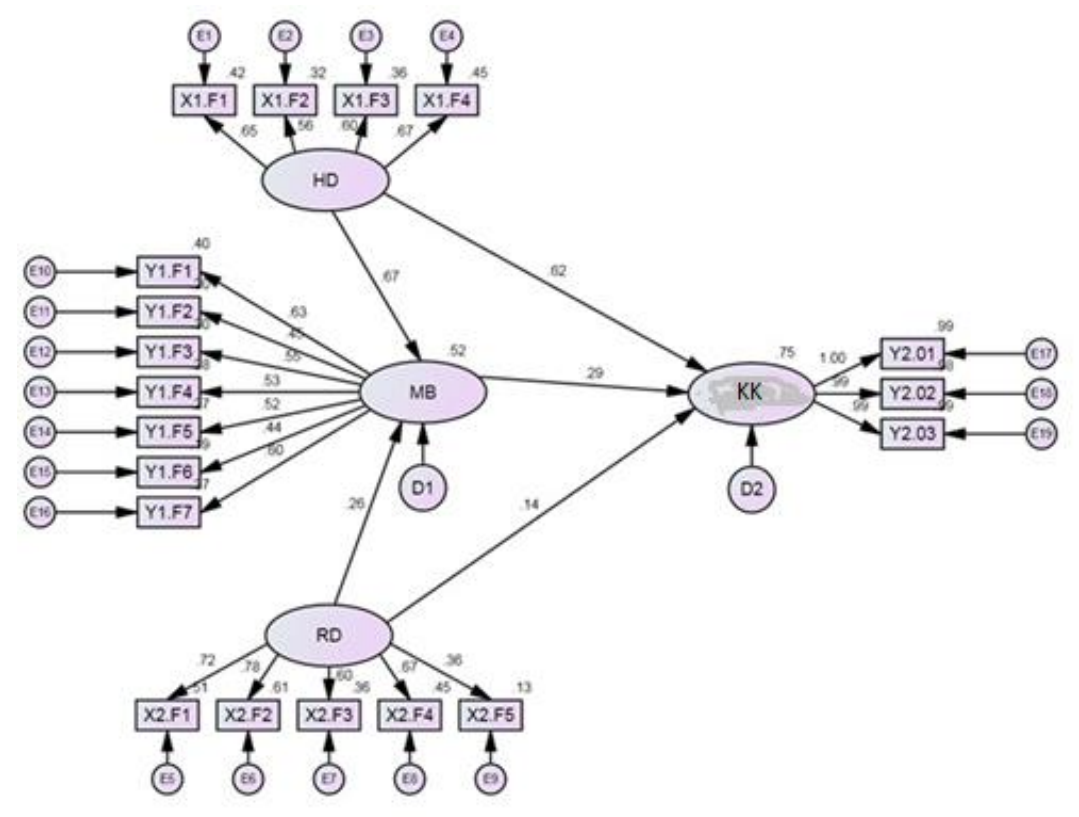

Hasil temuan setelah modifikasi Model struktural Teoritik Regulasi Diri, Motivasi Berprestasi, Harga Diri dengan Kematangan Karir Mahasiswa Bimbingan dan Konseling Islam IAIN Tulungagung

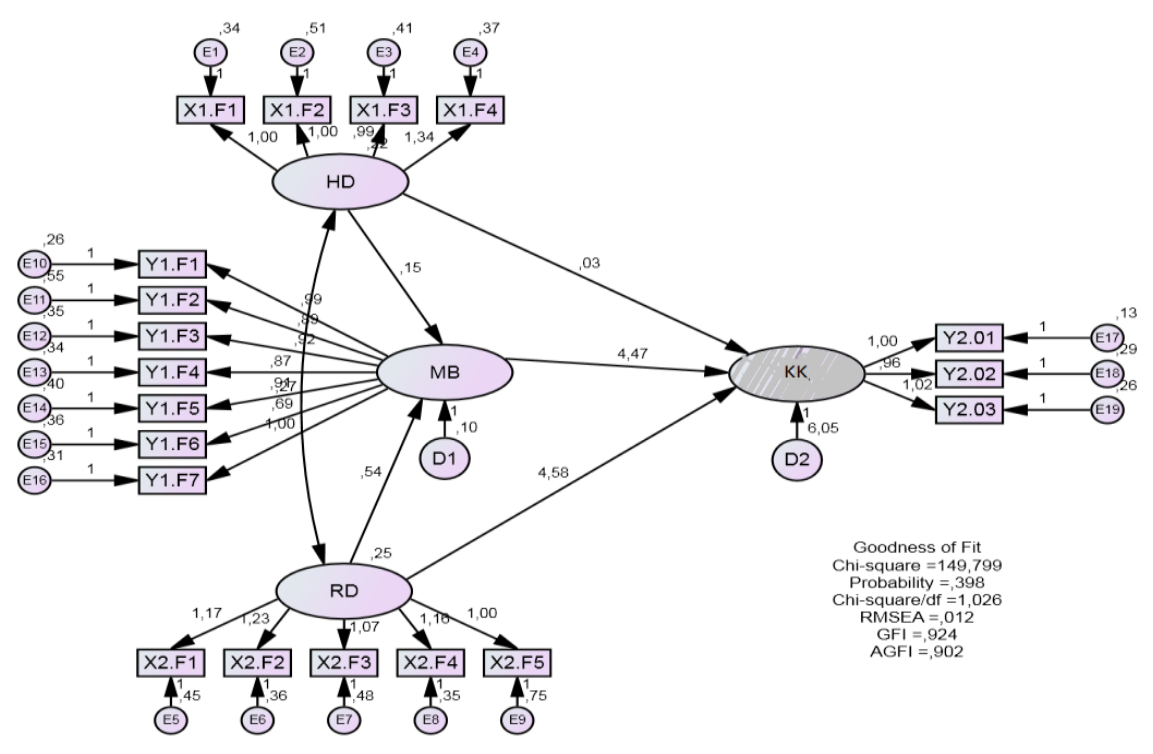


Gambar di atas menyajikan hasil yang diperoleh dari hasil analisis modifikasi model awal sesuai dengan saran modification indices dan hasil nilai rekomendasi untuk kelayakan model. Hasil uji kelayakan model pada modifikasi pertama memperoleh hasil yang baik semua yaitu CMIN/DF memiliki nilai sebesar 1.026 yang berarti baik, RMSEA memiliki nilai sebesar 0.012 yang berarti baik, GFI memiliki nilai sebesar 0.924 yang berarti baik, AGFI memiliki nilai sebesar 0.902 yang berarti baik, TLI memiliki nilai sebesar 0.998 yang berarti baik, CFI memiliki nilai sebesar 0.999 yang berarti baik.

\section{TEMUAN DESKRIPTIF SETIAP KONSTRUK PENELITIAN}

Konstruk harga diri (HD) sepenuhnya telah didukung oleh data empiris. Data deskriptif menunjukkan bahwa para mahasiswa bimbingan dan konseling islam yang memiliki harga diri (HD) tinggi cenderung (1) menerima kelebihan diri sendiri, (2) menerima kekurangan diri sendiri, (3) percaya terhadap kemampuan diri sendiri, dan (4) memiliki penilaian diri yang positif.

Konstruk regulasi diri (RD) juga didukung oleh data empiris bahwa mahasiswa bimbingan dan konseling islam yang memiliki regulasi diri tinggi (1) mampu membuat perencanaan terhadap diri sendiri, (2) mampu memotivasi diri sendiri, (3) mampu mengatur jalannya rencana tindakan, (4) bertindak dengan tepat untuk mencapai tujuan dan (5) mampu mengevaluasi hasil tindakan yang telah diambil.

Konstruk motivasi berprestasi (MB) telah diterima secara empiris, adapun data deskriptif yang menunjukkan motivasi berprestasi tinggi oleh mahasiswa bimbingan dan konseling islam yakni (1) bekerja keras untuk mencapai keberhasilan, (b) cenderung bertindak atau menetapkan suatu pilihan realistik, (c) menyukai situasi dimana dia dapat menilai kemajuan dan keberhasilan yang dicapai, (d) mampu memproyeksikan tujuan jangka panjang, (e) berorientasi pada tugas-tugas pemecahan masalah yang menantang, (f) percaya diri dalam menyelesaikan tugas, dan (g) menggunakan waktu secepat mungkin dan sebaik mungkin.

Konstruk Kematangan Karir (KK) telah diterima secara empiris, data deskriptif menunjukkan bahwa mahasiswa bimbingan dan konseling yang 
memiliki kematangan karir cenderung memiliki harga diri tinggi dan motivasi berprestasi yang tinggi, kemudian regulasi diri memberi sumbangan yang kecil kematangan karir mahasiswa bimbingan dan konseling islam.

\section{KESIMPULAN DAN SARAN \\ KESIMPULAN}

Berdasarkan hasil pengujian hipotesis harga diri mempengaruhi motivasi berpretasi, regulasi diri mempengaruhi motivasi berprestasi, harga diri mempengaruhi kematangan karir, regulasi diri mempengaruhi kematangan karir, Motivasi berprestasi mempengaruhi kematangan karir, dapat di simpulkan sebagai berikut:

1. Model teoritik kematangan karir mahasiswa bimbingan dan konseling islam yang telah dikembangkan mendapat dukungan empiris dan telah terbukti layak. Model tersebut dapat dirumuskan bahwa harga diri, regulasi diri, motivasi berprestasi memiliki pengaruh terhadap kematangan karir.

2. Hasil uji hipotesis dapat disimpulkan bahwa (a) harga diri secara signifikan dan berpengaruh positif terhadap motivasi berprestasi (b) regulasi diri secara signifikan dan berpengaruh positif terhadap motivasi berprestasi (c) harga diri secara signifikan dan berpengaruh positif terhadap kematangan karir(d) regulasi diri secara signifikan dan berpengaruh positif terhadap kematangan karir(e) motivasi berprestasi secara signifikan dan berpengaruh positif terhadap kematangan karir.

\section{SARAN}

Penelitian ini telah menyusun model teoritik kematangan karir yang menghubungkan dengan 3 variabel tentang aspek psikologis yang mendukung kematangan karir mahasiwa bimbingan dan konseling islam, di antaranya harga diri, regulasi diri, dan motivasi berprestasi. Untuk itu hasil penelitian ini diharapkan dapat gambaran bagi peneliti lain khususnya konselor yang akan melakukan penelitian lebih lanjut dalam topik terkait dan diharapkan dapat memperkuat bukti empiris mengenai hubungan antara motivasi berprestasi, regulasi diri, dan harga diri terhadap kematagan karir. 
Hasil dari penelitian ini, dapat digunakan sebagai analisis pada mahasiswa bimbingan dan konseling islam bahwa faktor yang mempengaruhi keberhasilan kematangan karir mahasiswa perlu mempertimbangkan aspek kognitif ada banyak faktor lain yang lebih mendukungnya, hendaknya konselor harus lebih memperhatikan aspek psikologis diantaranya harga diri, regulasi diri, dan motivasi berprestasi selain itu penelitian ini diharapkan dapat memperkaya repertoire konselor dalam membantu mahasiwa dalam meningkatkan kematangan karir.

\section{DAFTAR RUJUKAN}

Anastapsi. S \& Urbina, S. 2003. Psychological Testing, Seventh Edition. Upper Saddle River, NJ: Prentice-Hall International, Inc.

Atkinson R.L, Atkinson, R.C \& Hilgrad E.R. 2016. Pengantar Psikologi. Cetakan ketiga. Jakarta: Erlangga.

Baldwin, S. A., \& Hoffmann, J. P. (2012). The dynamics of self-esteem: A growth-curve analysis. Journal of Youth and Adolescence, 31, 101-113.

Bandura, A. 1977. Social Learning Theory. Englewood Cliffs, NJ: Prentice-Hall.

Bandura, A. 1986. Social Foundation of Thought and Action: A Social Cognitive Theory. Englewood Cliffs, New York: NJ. Prentice-Hall.

Creswell, J.W. 2012. Educational Reserch: Planing, Conducting, and Evaluating Quantitative Research. Boston: Pearson Education.

Gall, M.D. Gall, J.P. Borg, W.R. 2003. Educational Research: An Introduction, Seventh Edition. Allyn \& Bacon, Incorporated.

Patton W., dan Lokan (2001), Perspective of Donalt Super's Construct of Career Maturity, International Journal For Education and Vocational Guidance 1, $31-48$

Rakes, G. C. \& Dunn, K. E. 2013. The Impact of Online Graduate Students' Motivation and Self-Regulation on Academic Procrastination. Journal of Interactive Online Learning. 9 (1), Spring 2015.

Rothman, A. J, dkk. 2011. Self-Regulation and Behavioral Change: Disentangling Behavioral Initiation and Behavioral Maintenance. Dalam R. F. Baumiester \& K. D. Vohs. Handbook of Self-Regulation: Research, Theory, and Applications Second Edition. New York: The Guilford Press.

Santoso. S. 2005. Mengatasi berbagai masalah Statistik dengan SPSS Versi 11.5. Jakarta: PT Elex Media Komputindo.

Santoso. S. 2012. Analisis SEM Menggunakan AMOS, Jakarta: Elex Media Komputindo. 
JUANG: Jurnal Wahana Konseling (Vol. 2, No. 1, Maret 2019)

Sappaile, Baso Intang. 2007. Hubungan Kemampuan Penalaran dalam Matematika dan Motivasi Berprestasi Terhadap Prestasi Belajar Matematika. Jurnal Pendidikan dan Kebudayaan, 069, 985-1003

Senko, C. \& Harackiewicz, J. M. 2015. Regulation of Achievement Goal: The Role of Competence Feedback. Journal of Educational Psychology. Vol. 97, No. 3, 320-336.

Soedijarto. 2003. Pendidikan Nasional Sebagai Proses Transformasi Budaya. Jakarta : Balai Pustaka.

Subowo. E \& Martiarini. N.2017. Hubungan Antara Harga Diri Remaja Dengan Motivasi Berprestasi Pada Siswa Smk Yosonegoro Magetan. Jurnal Psikohumanika. Vol. 02. No1.

Zimmerman, B. J. \& Kitsantas, A. 2005. The Hidden Dimension of Personal Competence: Self-Regulated Learning and Practice. Dalam A. J. Elliot \& C. S. Dweck (Ed.). Handbook of Competence and Motivation. New York: Guilford Press.

Zimmerman, B.J., \& Schunk, D.H. 2001. Self Regulated Learning and Academic Achievement: Theoretical perspectives (2nd ed.). Mahwah, NJ: Erlbaum. 